\title{
KAJIAN ELEMEN ARSITEKTUR CINA STUDI KASUS: MASJID BABAH ALUN, JAKARTA
}

\author{
A study on Chinese Architectural Elements \\ Case Study: Babah Alun Mosque, Jakarta
}

Disetujui: 21 November 2021

\author{
Dian Monica Erveline Basri ${ }^{1}$, Silvia Shishiria ${ }^{1}$, Muhammad Fadlan Alfarisi ${ }^{1}$, Sheila Ayu Gayatri ${ }^{1}$ \\ ${ }^{1}$ Arsitektur, Tanri Abeng University \\ E-mail: monica.basri@tau.ac.id
}

\begin{abstract}
Abstrak
Bangsa Tionghoa yang datang dan menetap di Indonesia sudah memiliki sejarah yang panjang. Orang Tionghoa sudah mengenal Indonesia sejak abad ke $5 \mathrm{M}$, dan selama beberapa abad jumlahnya terus bertambah. Dari dulu hingga sekarang, orang-orang Tionghoa sudah memiliki andil dalam perkembangan bangsa Indonesia, dari segi budaya, seni, agama, dan lain-lain. Bentuk perwujudan Sino-Javanese Muslim Culture salah satunya dapat terlihat pada beberapa arsitektur masjid. Bentuk akulturasi budaya serta arsitektur tradisional Cina dengan Nusantara dalam bentuk bangunan salah satunya adalah bangunan Masjid Babah Alun. Penelitian ini bertujuan untuk mengidentifikasi elemen-elemen arsitektur tradisional Cina pada bangunan Masjid Babah Alun di Cilandak sehingga dapat diketahui elemen arsitektur dan budaya yang mempengaruhinya. Untuk mengindentifikasi elemen-elemen tersebut penelitian ini menggunakan teori arsitektur, arsitektur Islam dan arsitektur Cina sehingga menghasilkan perbandingan elemen- elemen dan hasil analisanya. Dar

i karakteristik arsitektur Masjid Babah Alun yang dijadikan obyek penelitian dapat diketahui bahwa 4 dari 7 elemen arsitektur serta ditambah 6 point nilai filosofis dari penggunaan elemen arsitektur Cina yang menyimpulkan bahwa Masjid Babah Alun termasuk bangunan yang mengaplikasikan arsitektur Cina.
\end{abstract}

Kata kunci: Elemen arsitektur, Islam, Cina, Masjid

PENDAHULUAN

Tionghoa merupakan etnis yang mampu mempertahankan eksistensinya di tempat, tanpa menghilangkan karakter budayanya. Fenomena ini menunjukan Etnis Tionghoa mampu mempertahankan identitas budayanya dari pengaruh budaya lain dari lingkungan yang berbeda. Keberlangsungan Budaya Tionghoa juga ditunjukan dengan konsistensi identitas arsitekturnya yang sangat khas sehingga menjadi simbol keberadaan mereka di tiap lingkungan. Bangsa Tionghoa yang datang dan menetap di Indonesia sudah memiliki sejarah yang panjang. Bangsa Tionghoa yang datang dan menetap di Indonesia sudah memiliki sejarah yang panjang. Dari dulu hingga sekarang, orang-orang Tionghoa sudah memiliki andil dalam perkembangan bangsa Indonesia, dari segi budaya, seni, agama, dan lain-lain. Fenomena akulturasi budaya contohnya banyak terdapat pada budaya Jawa, Islam, dan Tionghoa. Fenomena ini disebut sebagai Sino - Javanese Muslim Culture atau perpaduan Tionghoa, Jawa, Islam. Masjid di Cina memiliki karakteristiknya sendiri, tidak seperti masjid umum yang dipengaruhi oleh desain masjid di Timur Tengah. Atap adalah salah satu ciri paling menonjol dalam arsitektur Cina, mulai dari bentuk atap yang melengkung dan ornamen yang memiliki bentuk dan makna tertentu. 
Salah satu masjid di Indonesia yang mengaplikasikan elemen arsitektur Cina adalah Masjid Babah Alun. Masjid yang berlokasi di Cilandak Barat, Jakarta Selatan ini memiliki keunikan tersendiri mulai dari bentuk, warna hingga atapnya.

Kehadiran masjid yang terletak di dekat gerbang tol Cilandak Utama ini menarik perhatian dari para pengguna jalan tol yang melintas karena arsitekturnya yang bernuansa oriental. Elemen tersebut dapat dilihat dari bentuk fisik bangunan masjid, misalnya dari atap masjid, ornamen- ornamen yang ada, serta warna-warna yang digunakan dalam arsitekturnya.

\section{METODE}

Dalam penelitian ini, pertama-tama akan dibahas tinjauan tentang elemen-elemen arsitektur, arsitektur masjid, dan arsitektur Cina. Kemudian dari studi kasus yang dipilih, masing masing elemen bangunannya akan dianalisa berdasarkan elemen-elemen arsitektur, arsitektur masjid, dan arsitektur Cina. Kemudian akan disimpulkan seberapa banyak kecocokan elemen-elemen arsitektur studi kasus yang dipilih dengan elemenelemen arsitektur Cina yang dijadikan landasan teori.

Variabel penelitian adalah bentuk visual, dengan indicator : bentuk atap, bentuk kolom dan balok, bentuk ornamen, bentuk dinding, bentuk tangga dan material, dengan indicator : material dan warna elemen arsitekturnya.

\section{LANDASAN TEORI \\ ELEMEN-ELEMEN ARSITEKTUR \\ Bidang Dasar}

Sebuah bidang horizontal yang terhampar sebagai sebuah figur di atas sebuah latar yang kontras mendefinisikan sebuah area ruang sederhana. Area ini dapat diperkuat secara visual dengan cara-cara berikut.
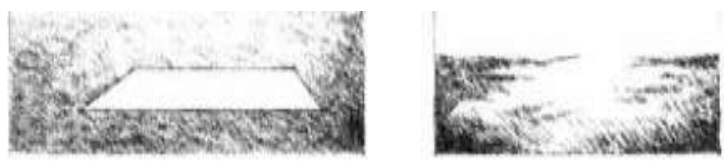

Gambar 1. Bidang Dasar

Sumber : Francis D K Ching, 1996

\section{Bidang Dasar yang Diangkat}

Bidang horizontal yang diangkat diatas bidang dasar menghasilkan permukaan - permukaan vertikal di sepanjang tepinya yang memperkuat perpisahan visual antara dengan bidang dasar di sekelilingnya.
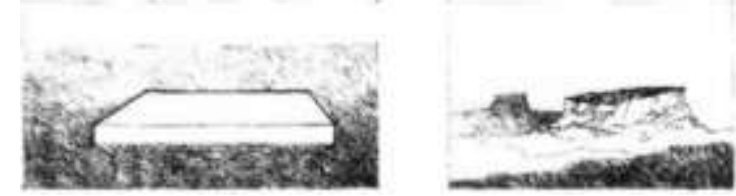

Gambar 2. Bidang Dasar yang Diangkat Sumber : Francis D K Ching, 1996

\section{Bidang Dasar yang Diturunkan}

Bidang horizontal yang diturunkan dari bidang dasarnya memanfaatkan permukaanpermukaan vertikal pada area yang lebih rendah untuk mendefinisikan sebuah volume ruang.
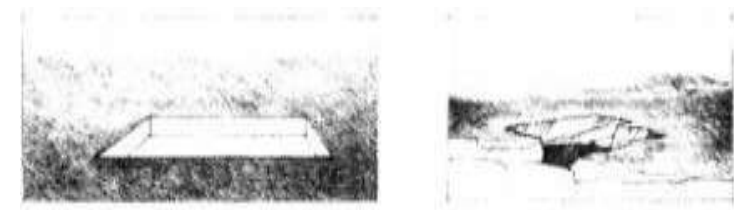

Gambar 3. Bidang Dasar yang Diturunkan Sumber : Francis D K Ching, 1996

\section{Bidang Di Atas}

Bidang horizontal yang diletakkan diatas mendefinisikan sebuah volume ruang antara dirinya sendiri dengan bidang dasarnya.
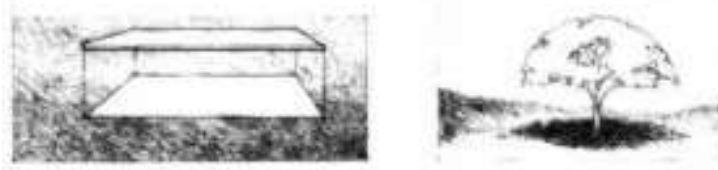

Gambar 4 : Bidang Diatas

Sumber : Francis D K Ching, 1996

\section{Elemen-elemen Linier Vertikal}

Elemen-elemen linier vertikal mendefinisikan tepi-tepi tegak lurus suatu volume ruang. 

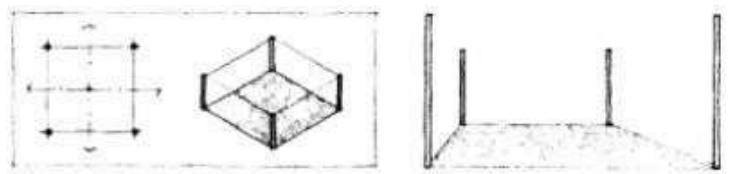

Gambar 5 : Elemen Linier Vertikal Sumber : Francis D K Ching, 1996

\section{Bidang Vertikal tunggal}

Sebuah bidang vertikal akan menegaskan ruang di hadapannya.
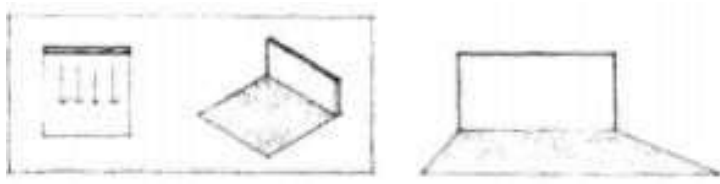

Gambar 6 : Elemen Vertikal Tunggal Sumber : Francis D K Ching, 1996

\section{Bidang Berbentuk L}

Sebuah konfigurasi bidang - bidang vertikal yang berbentuk $L$ akan memunculkan area ruang dari sudutnya keluar searah dengan sumbu diagonalnya.
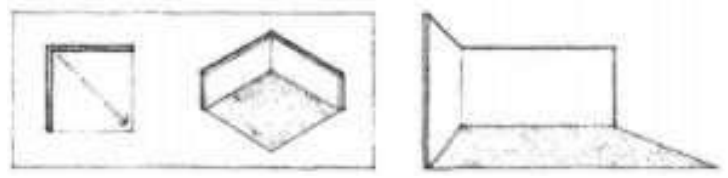

Gambar 7 : Bidang Berbentuk L Sumber : Francis D K Ching, 1996

\section{Bidang - bidang Sejajar}

Dua bidang vertikal yang sejajar akan mendefinisikan volume ruang di antara mereka yang diorientasikan mengikuti sumbu di kedua ujung terbuka konfigurasi tersebut.

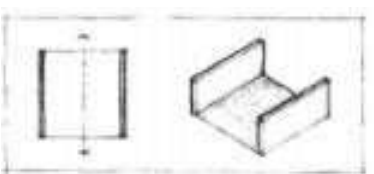

Gambar 8 : Bidang Sejajar

Sumber : Francis D K Ching, 1996

\section{Bidang-bidang berbentuk $U$}

Sebuah konfigurasi bidang-bidang vertikal yang mendefinisikan huruf $U$ akan mendefinisikan volume ruang yang diorientasikan terutama menuju ujung terbuka pada konfigurasi tersebut.
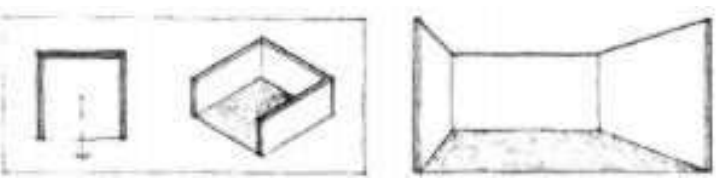

Gambar 9 : Bidang Sejajar Sumber : Francis D K Ching Hal, 1996

\section{Empat Bidang Penutup}

Empat bidang vertikal akan menciptakan batas - batas ruang yang tertutup serta mempengaruhi area ruang disekeliling penutupnya.



Gambar 10 : Bidang Penutup

Sumber : Francis D K Ching, 1996

\section{Kolom}

Dua buah garis yang sejajar mampu menggambarkan sebuah bidang secara visual. Sebuah membran spasial yang tembus pandang dapat direntangkan di antara garisgaris tersebut untuk mengukuhkan hubungan visual mereka. Semakin rapat jaraknya satu sama lain, semakin kuat pulalah kesan bidang yang dibawakannya.

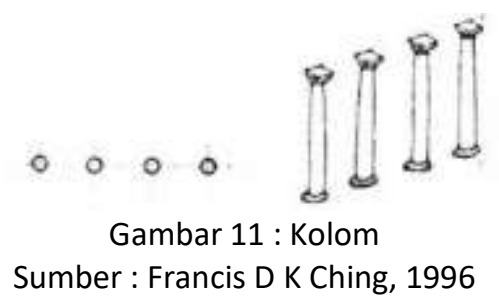

\section{Atap}

Seperti halnya pohon rindang yang memberikan rasa ternaungi di bawah payungnya, sebuah bidang atas mendefenisikan suatu area dengan ruang antara dirinya sendiri dengan bidang lantai dasarnya. Karena tepi - tepi bidang ataslah yang menentukan batas areanya, maka bentuk dasar, ukuran, serta ketinggiannya di atas bidang dasar akan menentukan kualitas ruang sesungguhnya. 



Gambar 12 : Bidang dasar dan Penutup Sumber : Francis D K Ching, 1996

Jika manipulasi - manipulasi terhadap bidang lantai atau bidang dasar mendefinisikan lingkup ruang yang batas atasnya tercipta oleh lingkungannya, maka lain halnya dengan bidang atas yang memiliki kemampuan mendefinisikan volume yang terpisah hampir oleh dirinya sendiri.
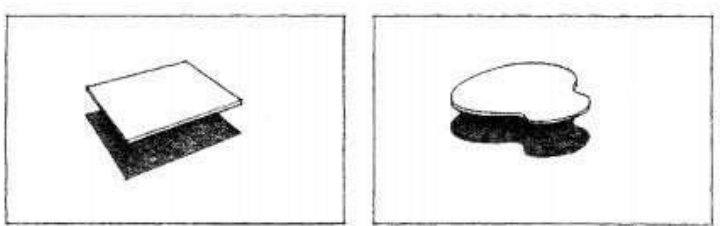

Gambar 13: Bidang Atas

Sumber : Francis D K Ching, 1996

Jika elemen-elemen linier yang vertikal seperti kolom atau tiang digunakan untuk menopang bidang atas, maka mereka akan membantu memvisualisasikan batas - batas ruang yang didefinisikan tampa mengganggu aliran ruang yang melalui area tersebut.
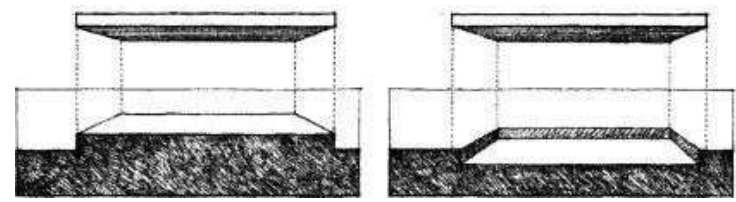

Gambar 14 : Batas - batas Ruang

Sumber : Francis D K Ching, 1996

Serupa halnya jika tepi-tepi bidang atas tersebut dibalik, atau bidang dasar dibawahnya ditegaskan dengan mengubah ketetinggian lantai, maka batas-batas volume yang didefinisikan akan diperkuat secara visual.


Gambar 15 : Batas Volume

Sumber : Francis D K Ching, 1996

\section{ELEMEN-ELEMEN ARSITEKTUR MASJID Minaret}

Minaret adalah menara yang letaknya di dekat/dibangun pada struktur sebuah masjid, yang digunakan oleh muadzin (juru azan) untuk mengumandangkan adzan yang mengajak umat muslim untuk berdoa/sembahyang.



Gambar 16 : Minaret

Sumber : www.google.com/search?q=Minaret, 2020

\section{Kubah}

Kubah merupakan salah satu unsur arsitektur yang selalu digunakan. la berbentuk seperti separuh bola, atau seperti kerucut yang permukaannya melengkung keluar. Biasanya kubah akan diletakkan di tempat tertinggi di atas bangunan (sebagai atap). la diletakkan di atas rangka bangunan petak bangunan.

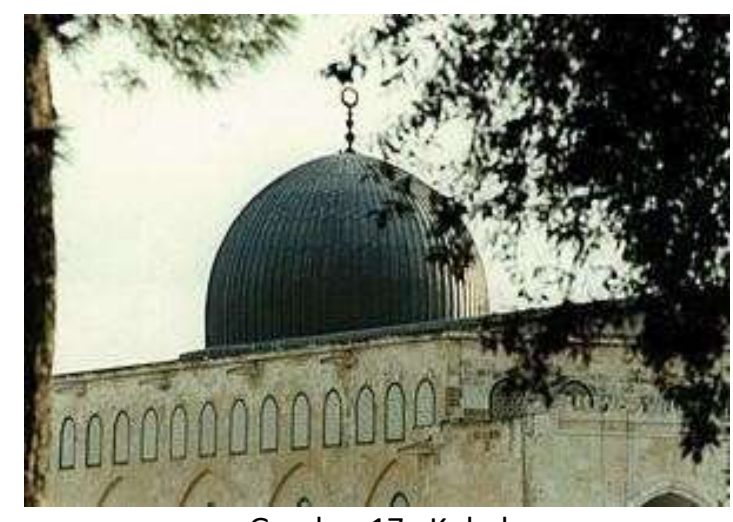

Gambar 17 : Kubah

Sumber : www.google.com/search?q=Kubah, 2020

\section{Mihrab}

Mihrab adalah ceruk setengah lingkaran atau tempat kecil yang ada di dinding paling depan 
masjid atau mushala yang menunjukkan arah kiblat dan merupakan tempat untuk Imam memimpin shalat berjemaah dalam suatu masjid.

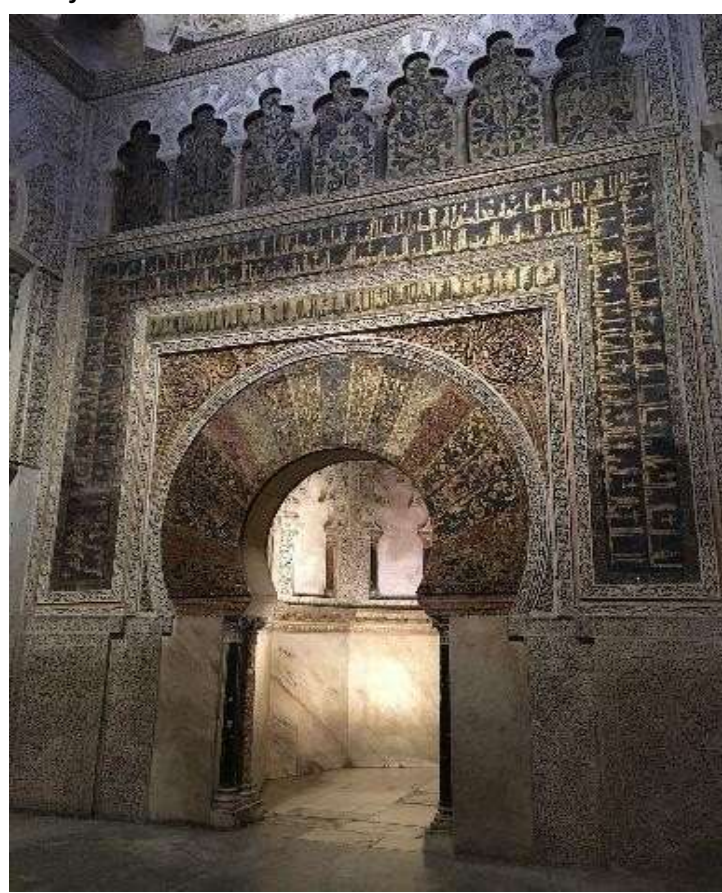

Gambar 18 : Mihrab

Sumber : www.google.com/search?q=Mihrab, 2020

\section{Mimbar}

Mimbar berada di dalam masjid letaknya di samping mihrab. Mimbar merupakan tempat khatib berkhotbah pada hari Jumat, atau saat Jumatan. Mimbar kemudian mempunyai fungsi yang cukup penting untuk komunikasi.

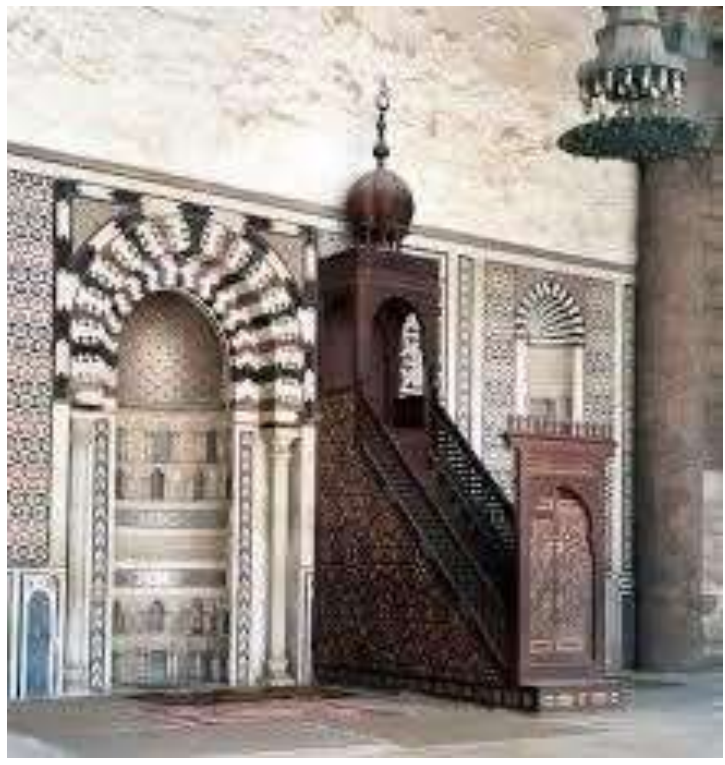

Gambar 19: Mimbar

Sumber : www.google.com/search?q=Mimb, 2020

\section{Ornamen}

Ornamen Masjid adalah sebuah elemen hiasan/dekorasi ataupun kaligrafi islam yang terdapat pada bangunan arsitektural masjid baik di dalam (interior masjid) maupun di luar bangunan (exterior masjid).

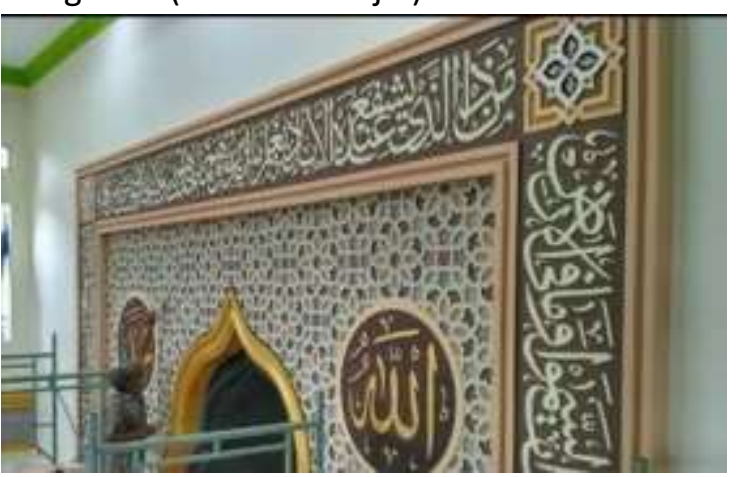

Gambar 20 : Ornamen Masjid

Sumber : www.google.com/search?q= ornamen Masjid, 2020

\section{ELEMEN-ELEMEN ARSITEKTUR CINA Podium Dan Lantai}

Bangunan tradisional Cina umumnya dibangun diatas lantai keras yang terbuat dari tanah, batu atau bata yang dinaikan dari permukaan tanah. Dasar lantai ini berguna untuk menopang beban bangunan agar tidak terjadi deformasi bentuk.

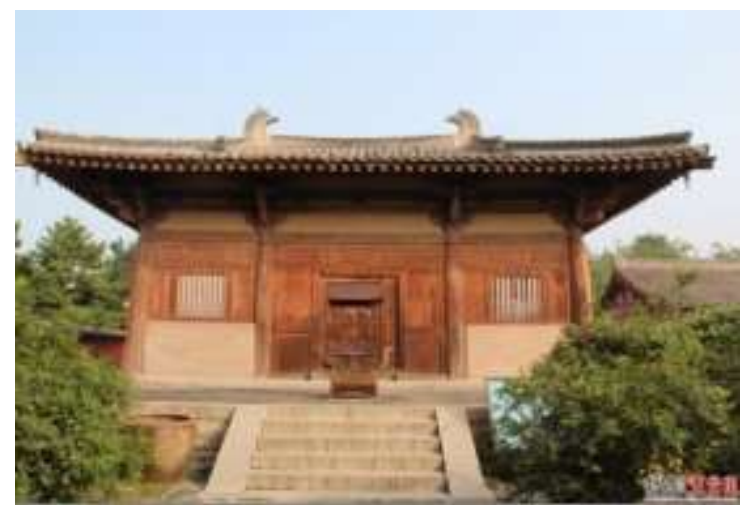

Gambar 21: Lantai batu pada bangunan tradisional Cina.

Sumber: https://www.chinadaily.com.cn/ m/ shanxi/wutaishan/201501/08/content19271797.ht m, 2020

\section{Pilar Dan Dinding}

Pilar

Kolom dan dinding biasanya dilapisi dan dicat dengan satu warna, seperti warna merah untuk bangunan kerajaan dan kuil, yang memberikan kesan sederhana yang kontras dengan dekorasi atap yang berwarna-warni. 
Hanya pola kisi-kisi pada pintu dan jendela yang memisahkan kesatuan antara dinding dan kolom. Pada kebanyakan bangunan, pilar terbuat dari batang kayu pohon pinus. Pilar biasanya akan ditempatkan diatas pedestal yang terbuat dari batu supaya tidak lapuk dan terkena rayap. Pada bangunan- bangunan besar, pedestal batu ini biasanya dihiasi oleh pahatan. Pahatan yang populer adalah pahatan berbentuk bunga teratai mekar yang diambil dari simbolisme agama Buddha.

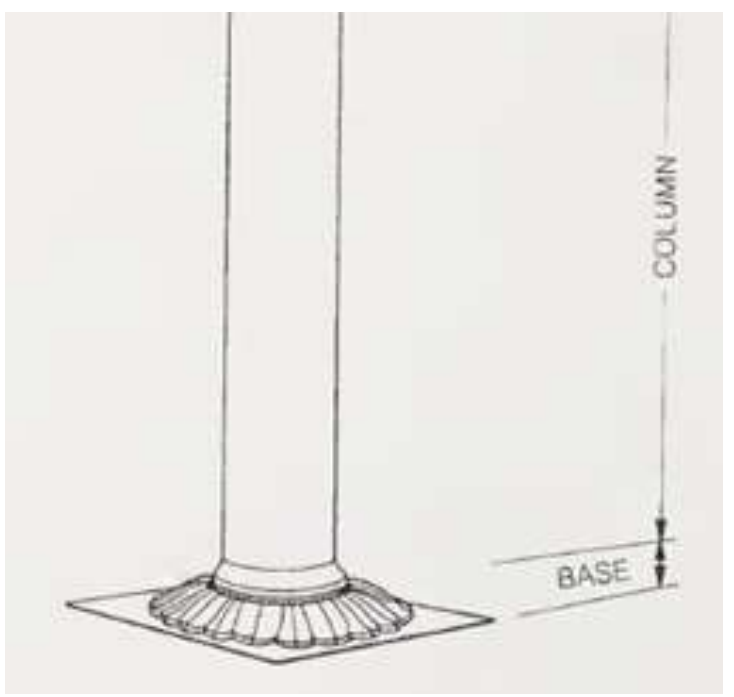

Gambar 22 : Pilar dan pedestal

Sumber: Charis Chan, Imperial China, (London, Penguin Books, 1991)

\section{Dinding}

Pada kebanyakan bangunan tradisional, semua beban atap ditopang oleh kolomkolom kayu, bukan oleh dinding. Karena kolom yang menopang semua beban atap, maka perancang dapat dengan bebas menempatkan dinding, jendela dan pintu, sehingga sering dijumpai bangunanbangunan besar memiliki dinding yang tipis dan ringan disertai dengan kisi-kisi motif. Di Cina bagian selatan di mana iklimnya panas dan lembap, sering kali sisi bangunan yang menghadap ke selatan dibiarkan terbuka atau diberikan bingkai kisi-kisi motif agar sirkulasi udara berjalan dengan baik. Sebaliknya, bangunan di Cina bagian utara yang memiliki iklim sub tropis, bangunan harus terlindungi dari dingin pada musim dingin dan harus memiliki sirkulasi udara yang baik ketika musim panas, maka digunakan pintu lipat yang dapat dibuka ketika musim panas.

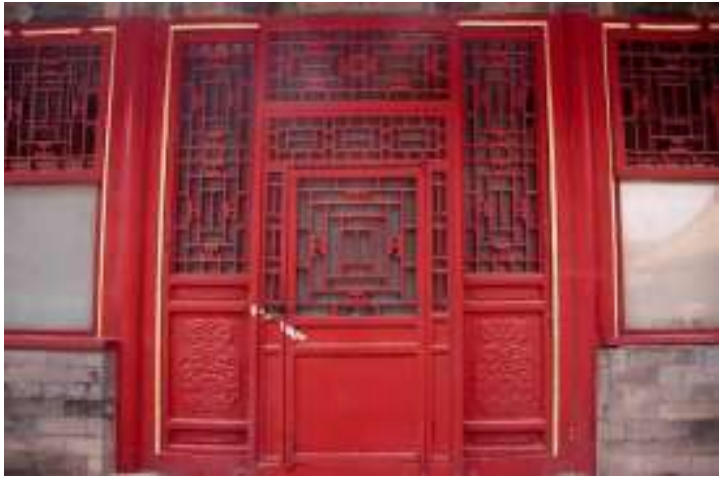

Gambar 23 : Pintu tradisional Cina

Sumber: https://www.flickr.com/photos/sensaos/ 4790827069/in/pool-15116517@N00/, 2020

\section{Atap \\ Bentuk Atap}

Pada bangunan tradisional, perancang merencanakan bangunannya didasari oleh jarak antar kolom yang dibutuhkan pada bangunannya. Kemudian atap akan dirancang sesuai dengan panjang dan lebar bangunannya. Bentuk atap pada bangunan tradisional Cina dibagi ke dalam 5 jenis, yaitu:

\section{Atap Pelana}

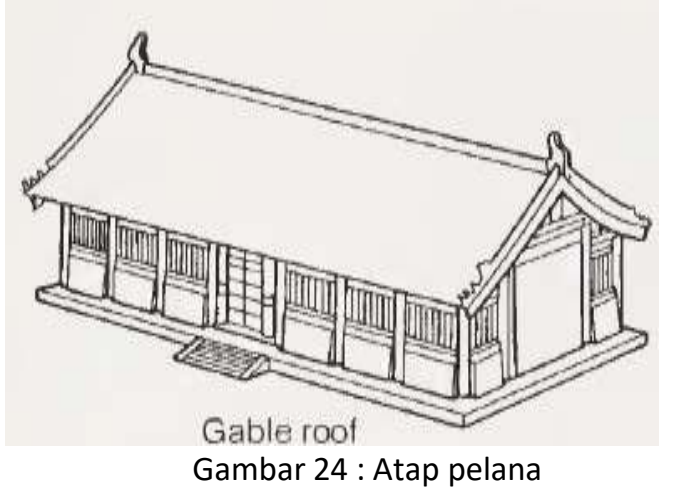

Sumber: Charis Chan, Imperial China, (London, Penguin Books, 1991)

\section{Atap Limasan}

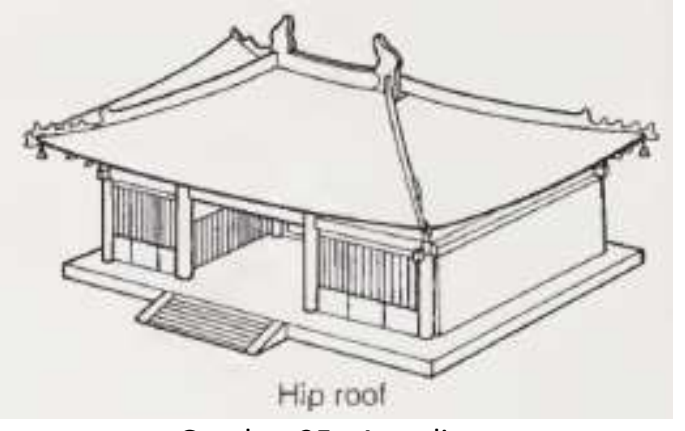

Gambar 25 : Atap limasan

Sumber: Charis Chan, Imperial China, (London, Penguin Books, 1991) 


\section{Atap Limas Pelana}

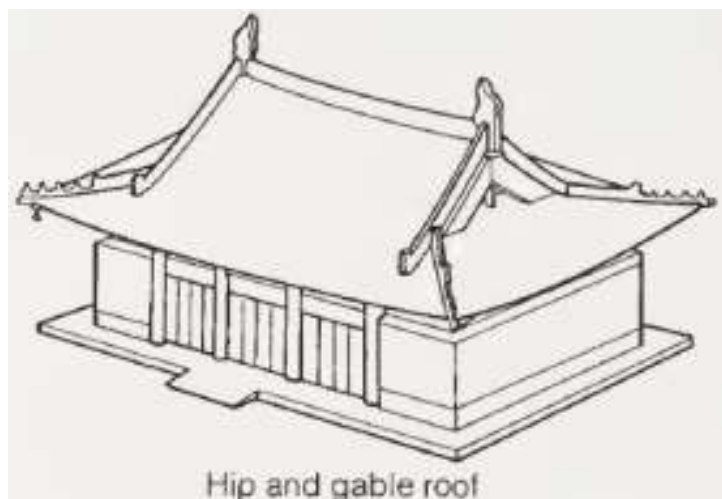

Gambar 26 : Atap limas pelana

Sumber: Charis Chan, Imperial China, (London, Penguin Books, 1991)

\section{Atap Limasan Ganda}

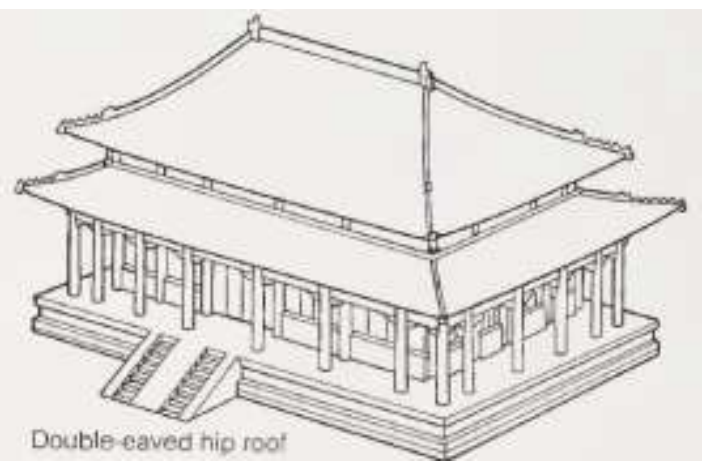

Gambar 27 : Atap limas ganda Sumber: Charis Chan, Imperial China, (London, Penguin Books, 1991)

\section{Atap Tajug}

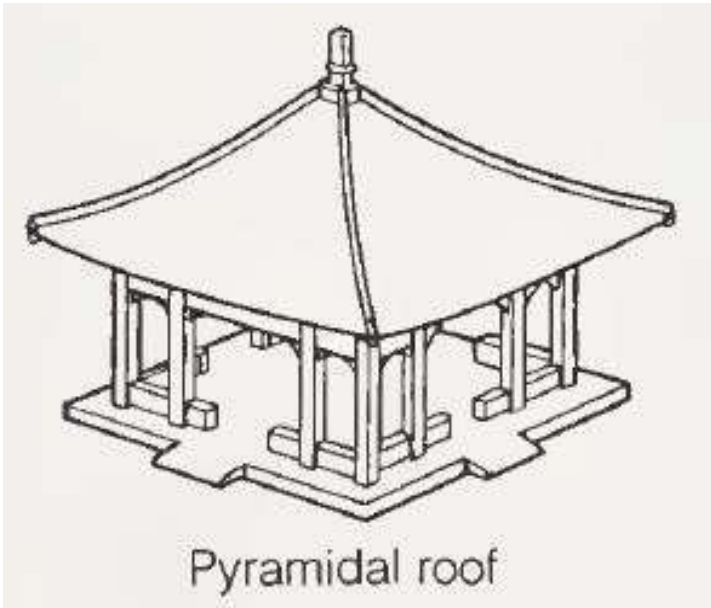

Gambar 28 : Atap tajug

Sumber: Charis Chan, Imperial China, (London, Penguin Books, 1991)
Zaman dahulu bangunan-bangunan penting biasanya berbentuk limas atau limas ganda. Sementara bangunan istana yang tingkatannya lebih rendah menggunakan atap limas pelana. Kemudian rumah-rumah rakyat menggunakan atap berbentuk pelana. Pada arsitektur bangunan tradisional di Cina bagian selatan, sejalan dengan perkembangan tradisi mengakibatkan bentuk atap dengan lengkungan-lengkungan yang dalam. Jurai yang melengkung tajam, dan bubungan atap melengkung tinggi. Di sisi yang lain, arsitektur tradisional Cina bagian utara yang lebih bernuansa kerajaan memiliki atap yang tidak terlalu melengkung. Dalam hal warna dan dekorasi atap pun setiap wilayah berbedabeda. Utara populer dengan warna-warna primer yang terang, daerah Timur dengan warna hitam, abu-abu dan hijau, daerah Selatan dengan warna yang beragam disertai ornamen-ornamen yang rumit.

\section{Genteng (琉璃瓦 liúlíwă)}

Genteng yang divernis adalah material yang berkelas tinggi pada bangunan jaman dahulu di Cina, yang hanya digunakan di bangunanbangunan istana, kuil dan bangunan pejabat tinggi negara. Warna genteng biasanya adalah kuning, hijau, biru dan hitam. Genteng yang dilapisi dengan warna tersebut bukan hanya memperindah bangunan, namun pada jaman dahulu juga menunjukkan status sosial penghuninya. Genteng berwarna kuning dikhususkan bagi bangunan istana kerajaan, makam, taman kerajaan dan kuil. Karena warna kuning disebut sebagai warna Sungai Kuning yang dipercaya sebagai tempat lahir peradaban bangsa Cina. Warna kuning mempresentasikan elemen tanah yang menjadi pusat alam semesta dan hanya boleh digunakan oleh penguasa. Warna hitam mempresentasikan elemen air dan genteng berwarna hitam diartikan sebagai air yang selalu siap untuk memadamkan api. Sementara warna biru mempresentasikan surga dan biasa ditemukan pada bangunan kuil.

Pada bangunan kerajaan, warna genteng kuning biasa disandingkan dengan tembok berwarna merah karena warna merah mempresentasikan kebahagiaan dan 
kegembiraan. Tembok berwarna merah hanya dapat digunakan pada bangunan istana dan kuil, karena kombinasi tembok merah dan genteng kuning digunakan untuk membangkitkan suasana bahagia dan khidmat.

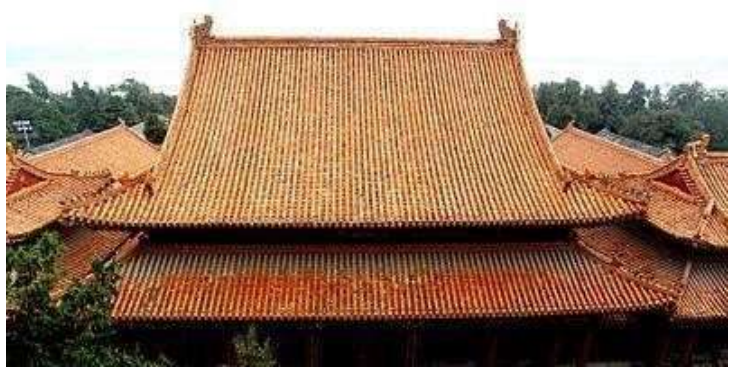

Gambar 29 : Genteng bangunan tradisional Cina Sumber:

https://wikimili.com/en/Chinese_glazed_roof_tile, 2020

\section{Duogong (斗拱 dǒugǒng)}

Duogong adalah sistem pengunci tumpuan balok yang unik pada bangunan tradisional Cina. Tumpuan ini dibuat bertumpuk untuk menyangga overhang atap dan tampilannya juga menambah kesan mewah pada bangunan. Sistem pengunci Duogong dapat ditemukan pada ujung atas kolom bangunan dan pertemuan antar balok pengikat struktur. Karena batasan hierarkis dalam masyarakat feodal kala itu, stuktur Duogong hanya dapat ditemukan pada bangunan yang besar seperti istana dan kuil. Jumlah tumpukan pada sistem Duogong juga menentukan seberapa penting bangunan itu. Gambar 30 :

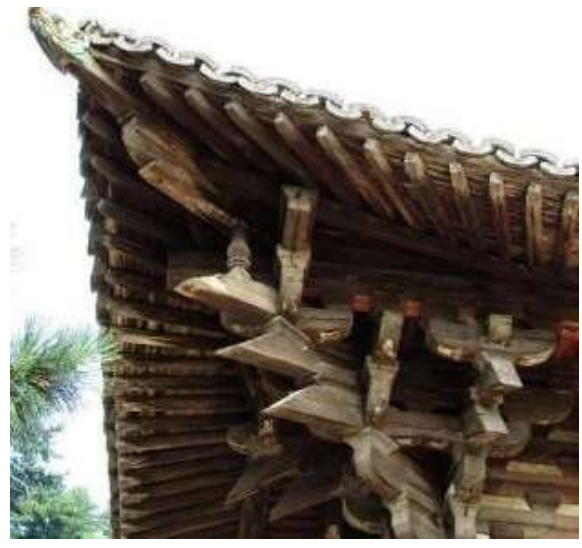

Gambar 30 : Sistem Duogong Sumber:

http://www.newsancai.com/gb/traditio nal/, 2020

\section{Wenshou (吻兽 wěnshòu)}

Bangunan tradisional Cina seperti istana, kuil dan rumah besar lainnya memiliki ornamen spesial berbentuk binatang pada bubungan dan jurai atapnya yang disebut dengan Wenshou. Ornamen pada kedua ujung bubungan atap disebut dengan Chiwen, ornamen berbentuk ikan tersebut tampak seperti sedang menggigit ujung bubungan atap sehingga disebut juga sebagai tunjishou atau monster pelahap bubungan atap. Menurut mitologi Cina, ikan tersebut adalah salah satu anak dari dewa naga yang menguasai lautan. Masyarakat Cina kuno percaya bahwa ikan tersebut dapat mengangkat ombak dan mengubahnya menjadi hujan, sehingga mereka menempatkannya di atap supaya kekuatannya dapat menurunkan hujan ketika terjadi kebakaran.

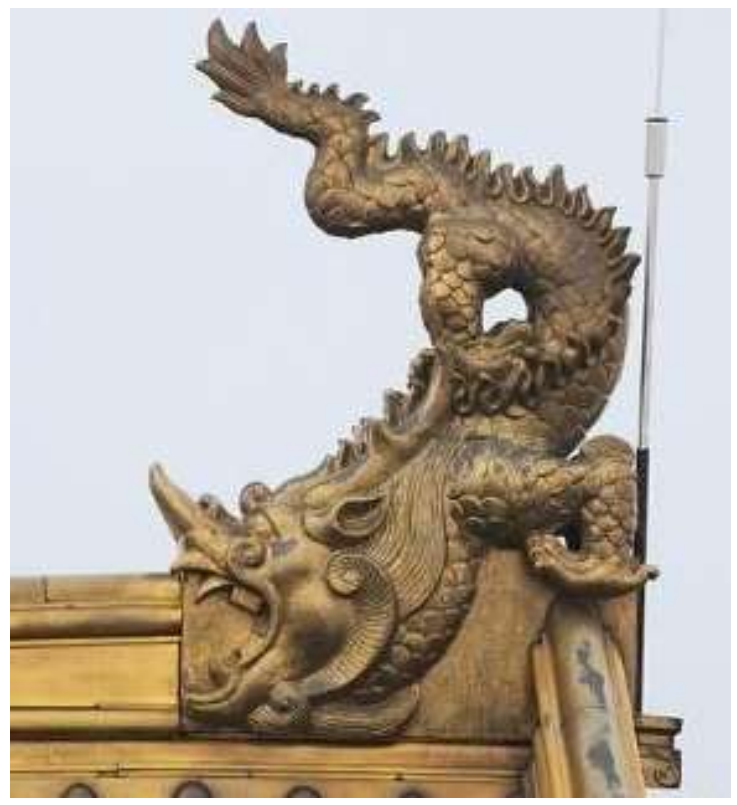

Gambar 31 : Ornamen Wenshou

Sumber: https://commons.wikimedia. org/wiki/File:Emeishan.jinding.chiwen.jpg, 2020

Di ujung jurai atap biasanya terdapat ornamen berbentuk barisan binatang yang ukuran dan jumlahnya tergantung kepada status pemilik bangunan tersebut. Ornamen ini biasanya berbentuk dewa yang sedang menunggang burung phoenix, naga, burung phoenix, singa, kuda, kuda laut dan lima hewan mitologi lainnya. Hewan-hewan ini juga dipercaya dapat memadamkan api. 


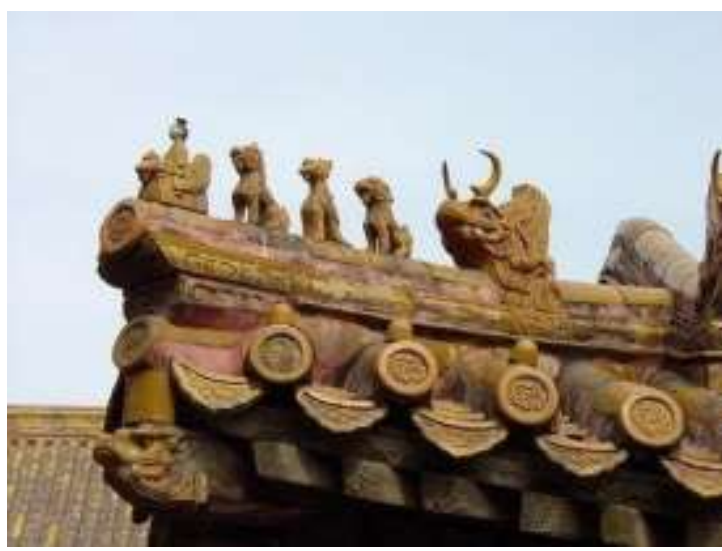

Gambar 32 : Ornamen wenshou

Sumber : http://www.art-and-

archaeology.com/china/beijing/fd05.html, 2020

Di hampir seluruh wilayah utara, ornamenornamen tersebut terbuat dari tanah liat yang dicetak sesuai dengan bentuk hiasannya. Berbanding terbalik dengan ornamen atap wilayah utara yang sederhana, wilayah selatan memiliki ornamen atap yang lebih megah dan rumit, baik pada bangunan rumah biasa, kuil bahkan kuburan. Bentuk ornamen atap di wilayah selatan dapat dibagi menjadi 5 tipe sesuai bentuknya, yaitu:

\section{Tipe tail feather corner (Qiajiao)}

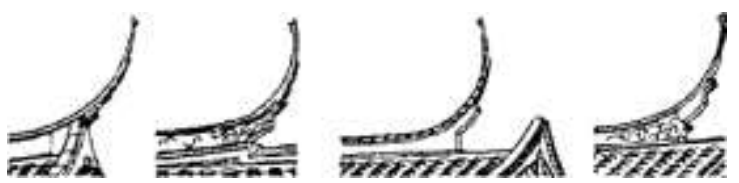

Gambar 33 : Tipe tail feather corner

Sumber : Ronald G. Knapp, China's Old Dwellings, 1999

Tipe martial ridge (Wuji)
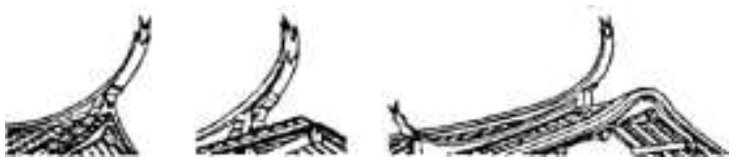

Gambar 34 : Tipe martial ridge

Sumber : Ronald G. Knapp, China's Old Dwellings. 1999

\section{Tipe civil ridge (Wenji)}


Gambar 35 : Tipe civil ridge

Sumber : Ronald G. Knapp, China's Old Dwellings, 1999

\section{Tipe pointed tip (Jianji)}
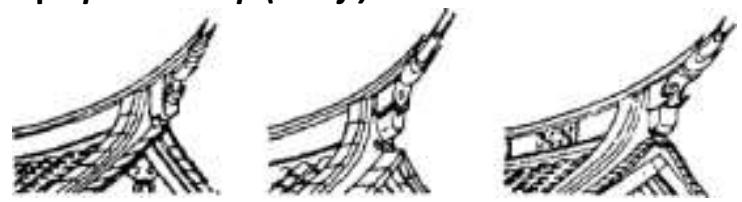

Gambar 36 : Tipe pointed tip

Sumber : Ronald G. Knapp, China's Old Dwellings, 1999

\section{Tipe rounded ridge (Yuanji)}
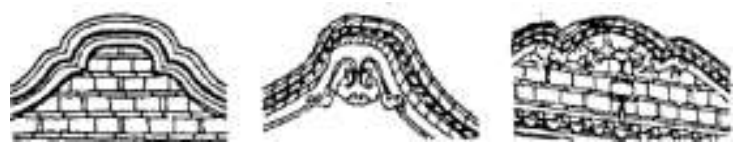

Gambar 37 : Tipe rounded ridge

Sumber : Ronald G. Knapp, China's Old Dwellings, 1999

\section{Mahkota atap (宝顶 Baoding)}

Salah satu ornamen struktur atap yaitu Baoding yang artinya "harta karun di puncak", terletak di pucuk atap yang berbentuk menara segi enam atau delapan dan tidak memiliki bubungan. Biasanya ornamen ini berbentuk kendi arak, vas, pagoda, dll yang terbuat dari tanah liat. Ornamen ini sering kali dikelilingi oleh pahatan berbentuk naga, phoenix, bunga peony, dan binatang lainnya. Ornamen ini bukan hanya sebagai hiasan melainkan juga digunakan sebagai pelindung struktur tiang utama pada atap yang kala itu terbuat dari kayu yang menjulang tinggi sampai ke pucuk atap. 


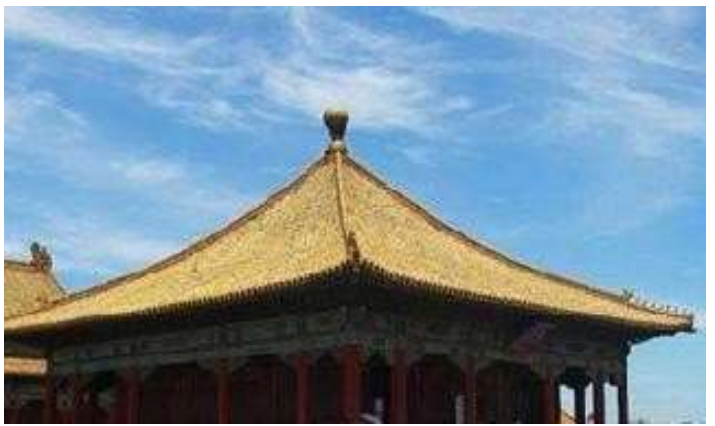

Gambar 38 : Baoding

Sumber :

http://www.chinadaily.com.cn/life/2011-

03/18/content_12191507.htm, 2020

\section{Penutup Genteng (瓦当 Wădàng)}

Penutup gedeng merupakan aksesoris arsitektur pada bangunan tradisional Cina sebagai dekorasi dan melindungi kaso dari hujan dan angin. Selama perkembangannya, penutup genteng berubah dari bentuk setengah lingkaran menjadi bentuk lingkaran penuh dan juga berubah dari bentuk datar menjadi ukiran. Ukiran yang terdapat pada penutup genteng bermacam-macam tergantung tema yang diterapkan, seperti tema ukiran alam, mitologi, sejarah, nama tempat, kalimat mutiara, cerita rakyat dan nama keluarga.

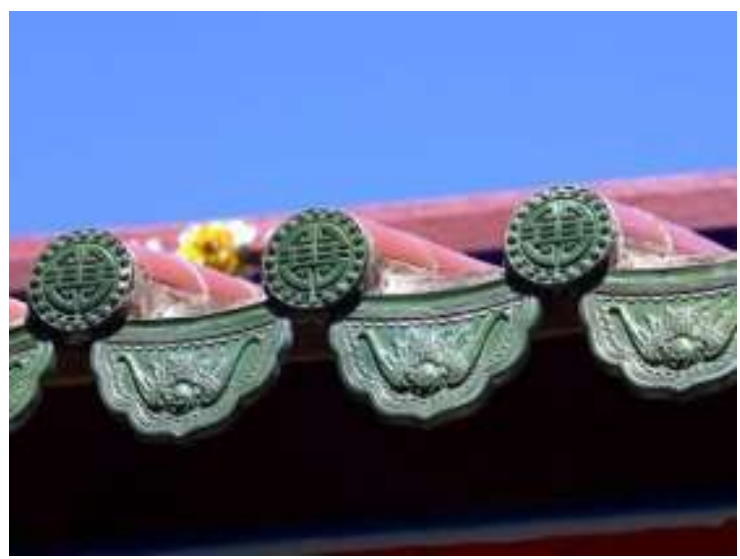

Gambar 39 : Wădàng

Sumber :

http://chindonews.blogspot.com/2018/10/wadan $\mathrm{g}$ - atau-atap-genteng-tradisional.html, 2020

\section{FILOSOFI WARNA}

Warna pada arsitektur Tionghoa memiliki arti atau makna simbolik. Warna-warna tertentu pada umumnya diberikan pada elemen- elemen tertentu pada bangunan karena warna merupakan salah satu penerapan dari aspek religi/kepercayaan masyarakat Tionghoa. Setiap warna memiliki arti atau makna tertentu, antara lain:

\section{Merah}

Warna merah merupakan warna api dan warna api dan warna arah selatan. Warna merah merupakan lambang keberuntungan dan kemakmuran, sekaligus melambangkan kebenaran dan ketulusan hati.

Warna merah seringkali dikaitkan dengan sifat Yang dari matahari. Pada arsitektur Tionghoa, warna merah sering terdapat pada kolom, dinding, dan ornamen-ornamen bangunan.

\section{Kuning}

Warna kuning merupakan warna tanah. Dalam arsitektur Tionghoa, dinding dan ornamen hias pada bangunan kelenteng seringkali diberi warna kuning. Warna kuning merupakan lambang kemakmuran dan sikap optimis, sekaligus lambing umur panjang dan kekayaan. Dalam sejarah Tionghoa, pakaian berwarna kuning hanya boleh dikenakan oleh Kaisar.

\section{Biru}

Warna biru merupakan warna dari elemen air dan mewakili arah timur, sekaligus melambangkan kedudukan dan jabatan. Warna biru seringkali digunakan pada bagian atap dan dinding.

\section{Hijau}

Dalam arsitektur Tionghoa, warna hijau sering diterapkan sebagai elemen dekorasi, balok, dan braket. Warna hijau merupakan symbol kayu dan melambangkan keberuntungan (rezeki yang melimpah).

\section{PEMBAHASAN}

\section{Data Eksisting Studi Kasus}

Berikut adalah data eksisting masjid babah alun cilandak :

Masjid Babah Alun memiliki arsitektur yang berbeda dari masjid pada umumnya di Indonesia. Masjid bernuansa China ini dibangun oleh anak angkat Buya Hamka, yaitu 
Muhammad Jusuf Hamka. Nama masjid ini diambil dari nama asli Jusuf Hamka. Dalam tradisi Tionghoa, babah memiliki arti 'ayah'. Sementara itu, Alun adalah nama asli Jusuf Hamka sebelum menjadi seorang mualaf, yaitu Alun Josef.

Masjid ini di bangun pada tahun 2019 dan di resmikan pada bulan Juli tahun 2020, lokasiMasjid Babah Alun yang berdiri tepat di pinggir jalan Tol Desari, Kecamatan Cilandak, Jakarta selatan.

Nuansa Pecinan terasa kental pada bangunan masjid, seperti pada bentuk atap, elemen elemen dan struktur terbuka, serta penggunaan warna yang khas yakni merah menyala, dengan dinding berwarna putih gading, yang jadi ciri khas masyarakat Tionghoa. Kusen pintu dibuat melingkar yang dihiasi ornamen Tionghoa berwarna merah dan kuning emas. Nuansa Islami juga terasa di antara corak Tionghoa dengan hadirnya lukisan kaligrafi pada pintu masuk dan juga pilar masjid.

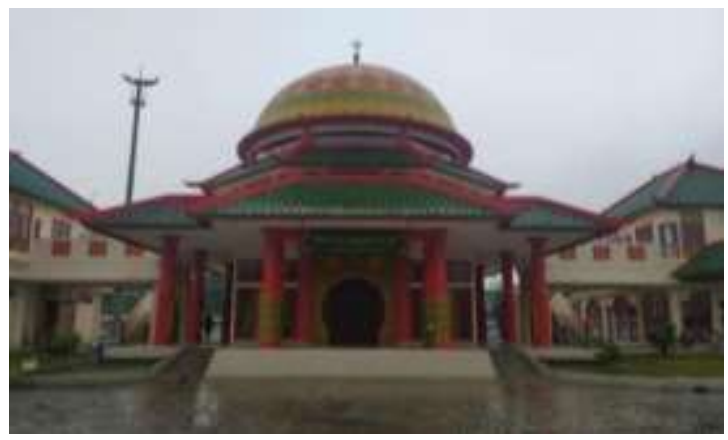

Gambar 40. Masjid Babah Alun Sumber: Dokumentasi Pribadi, 2020

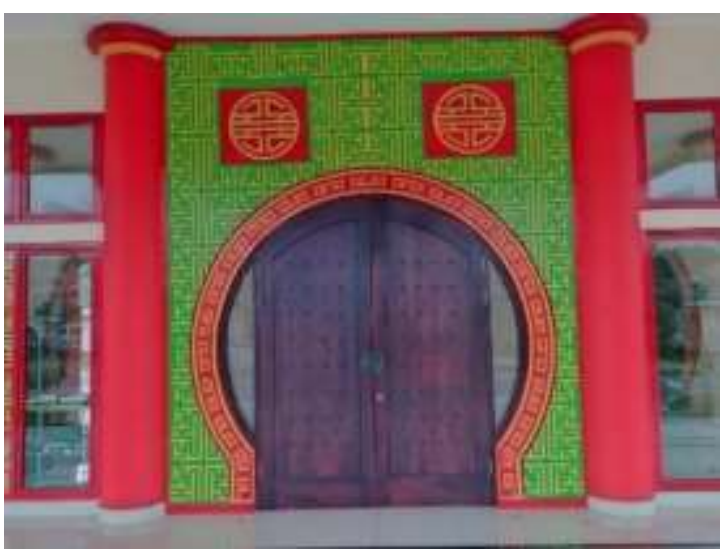

Gambar 41. Pintu Masuk Utama Sumber: Dokumentasi Pribadi, 2020

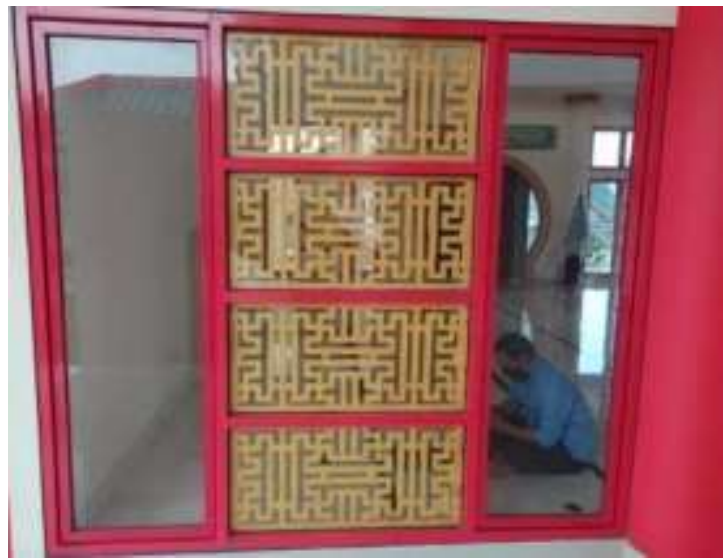

Gambar 42. Jendela

Sumber: Dokumentasi Pribadi, 2020

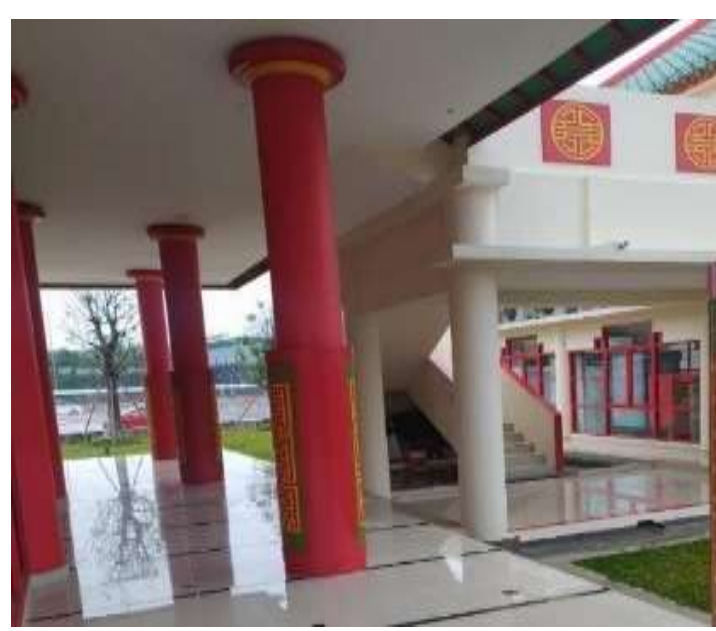

Gambar 43. Pilar Pelataran Masjid Sumber: Dokumentasi Pribadi, 2020

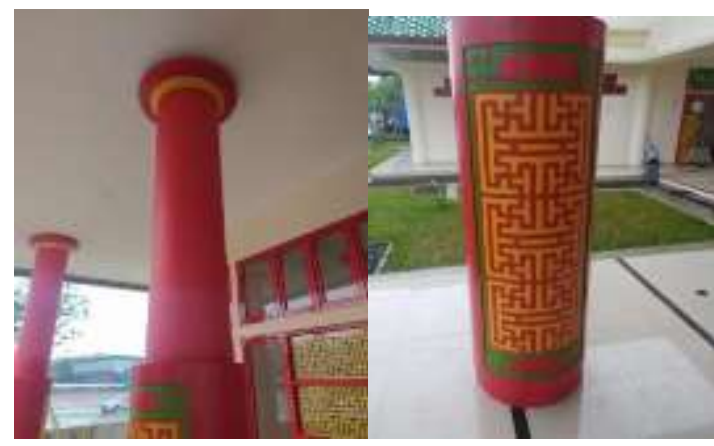

Gambar 44. Pelataran Masjid Sumber: Dokumentasi Pribadi, 2020 




Gambar 45. Pilar depan masjid

Sumber: Dokumentasi Pribadi, 2020

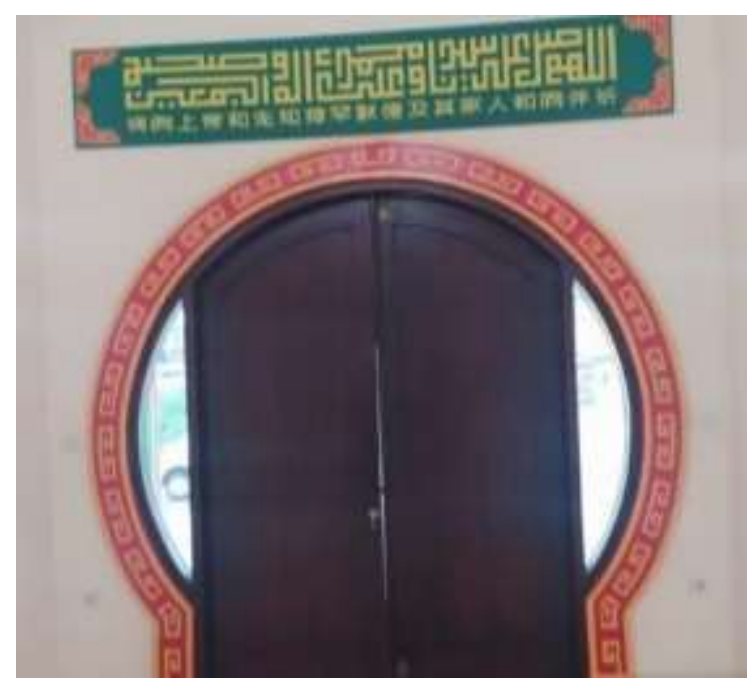

Gambar 46. Tampak Pintu dari Dalam Sumber: Dokumentasi Pribadi, 2020

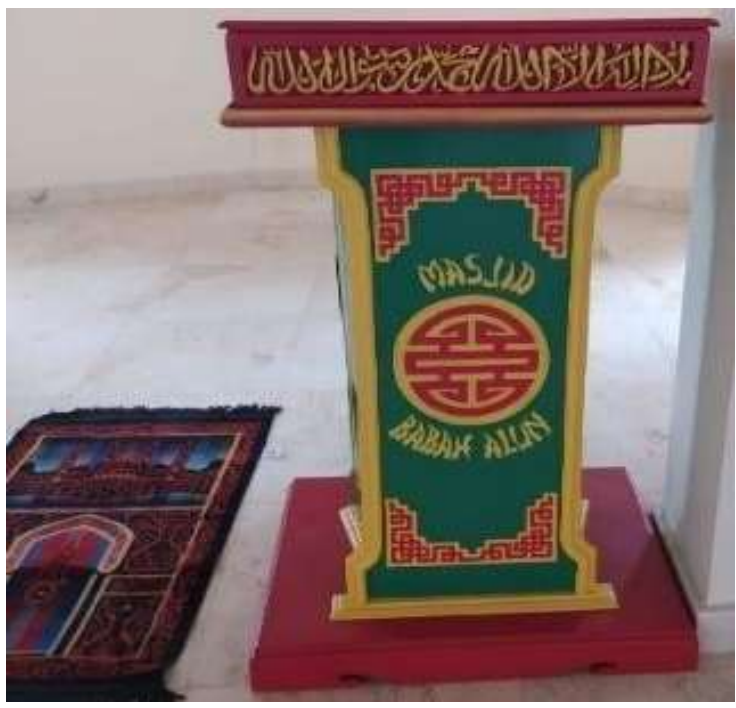

Gambar 47. Mimbar Masjid

Sumber: Dokumentasi Pribadi, 2020

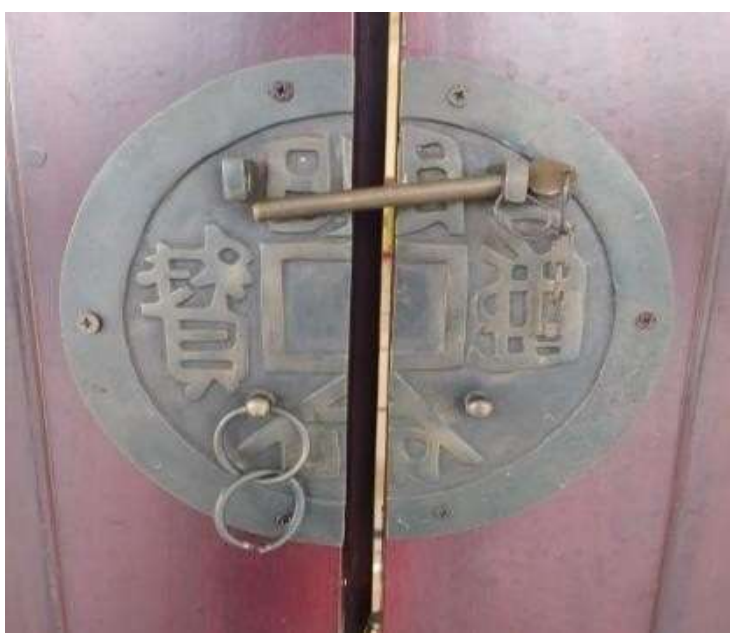

Gambar 48. Detail Ornamen Pintu Sumber: Dokumentasi Pribadi, 2020

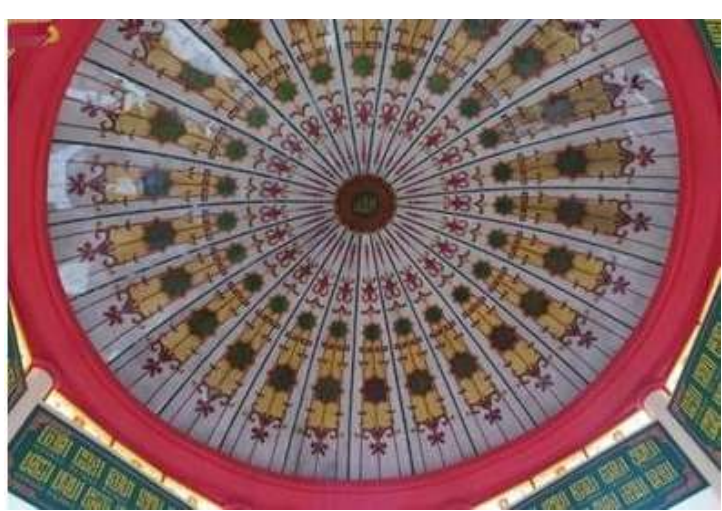

Gambar 49. Lukisan Kaligrafi Di Bagian Dalam Kubah Masjid Babah Alun

Sumber: Dokumentasi Pribadi, 2020

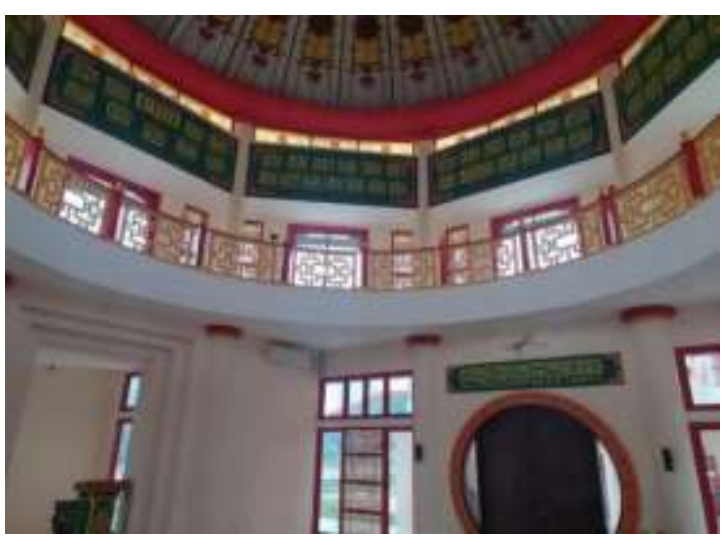

Gambar 50. Balkon Dalam Masjid Sumber: Dokumentasi Pribadi, 2020 


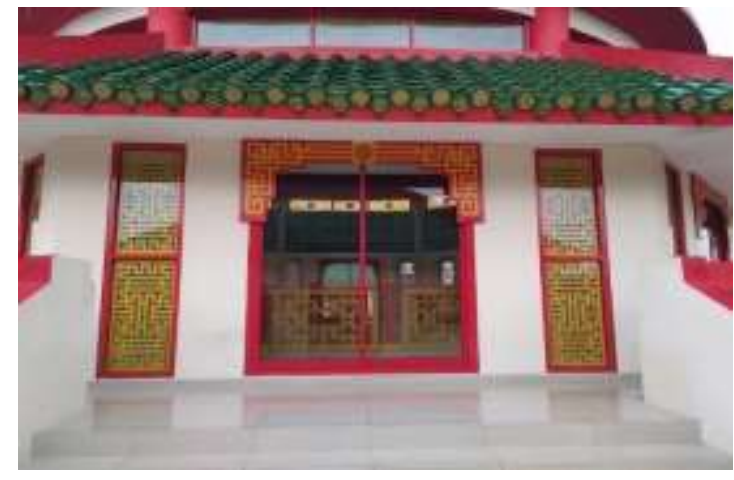

Gambar 51. Pintu dan Jendela Masjid Lantai 2 Sumber: Dokumentasi Pribadi, 2020

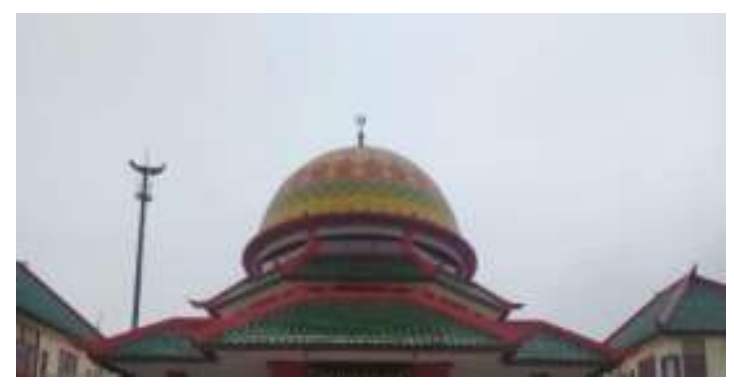

Gambar 52. Atap Masjid Sumber: Dokumentasi Pribadi, 2020

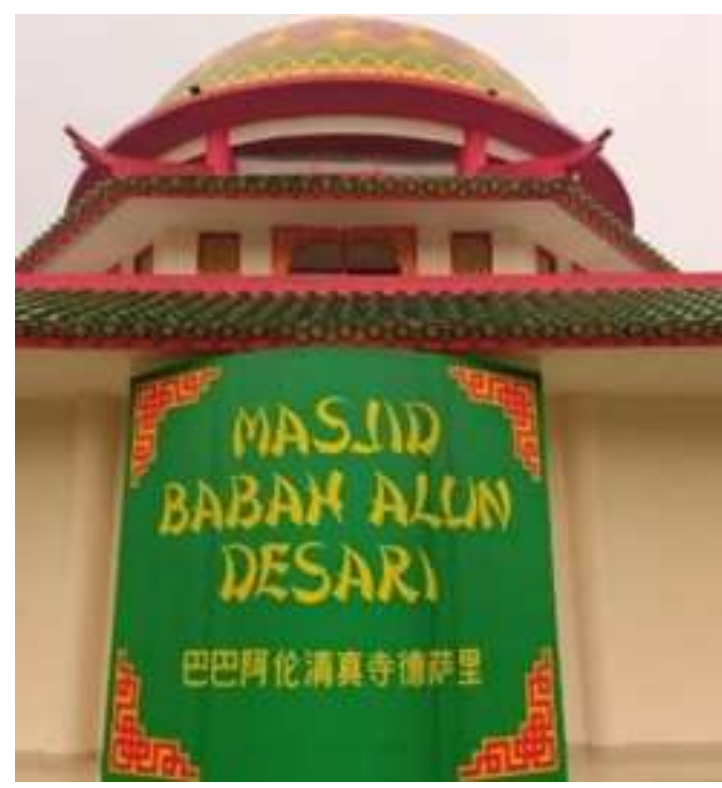

Gambar 53. Tulisan Masjid Babah Alun Sumber: Dokumentasi Pribadi, 2020

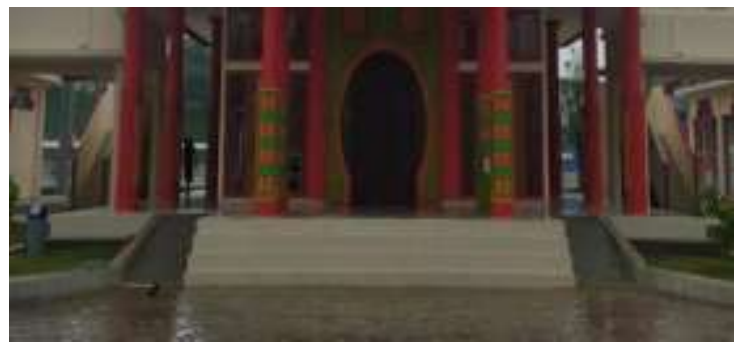

Gambar 54. Podium dan Lantai Masjid Sumber: Dokumentasi Pribadi, 2020

\section{ANALISA ELEMEN ARSITEKTUR STUDI KASUS}

Berikut adalah analisa elemen-elemen arsitektur pada bangunan Masjid Babah Alun yang di Cilandak.

Tabel 2: Analisa elemen arsitektur Masjid Babah Alun

\begin{tabular}{|c|c|c|c|c|}
\hline $\begin{array}{l}\text { Nama } \\
\text { Elemen }\end{array}$ & $\begin{array}{l}\text { Elemen } \\
\text { Arsiteitur } \\
\text { Masjid }\end{array}$ & \begin{tabular}{c|} 
Elemen \\
Arsitekur \\
Masis Babah \\
Alum
\end{tabular} & Analisa & Milai Flosafi \\
\hline Lamtai & & E & $\begin{array}{l}\text { Lartai memilki } \\
\text { posium dan } \\
\text { material lantai } \\
\text { terbuat dari lantai } \\
\text { keramik. }\end{array}$ & $\begin{array}{l}\text { Podium pada masjid di } \\
\text { pergunakan urtek } \\
\text { melaksanakan solat, } \\
\text { dan manusia } \\
\text { berkumpal umbik } \\
\text { sama-sama menyebah } \\
\text { Tuhan Yang Naha Esa. }\end{array}$ \\
\hline Dinding & & & $\begin{array}{l}\text { Dinding terbuat } \\
\text { dari material bata } \\
\text { dan semen } \\
\text { namumberwama } \\
\text { cream berbeda }\end{array}$ & $\begin{array}{l}\text { Warna crear pada } \\
\text { masjd, melambangkan } \\
\text { akan sudimfa masjd ini } \\
\text { sebagai terpat untuk }\end{array}$ \\
\hline $\begin{array}{l}\text { Booainglom } \\
\text { amen Ljure } \\
\text { Atap }\end{array}$ & & & 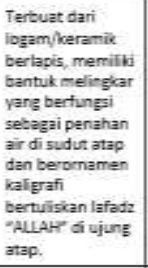 & 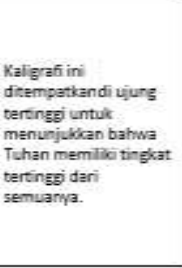 \\
\hline Genterg & & & $\begin{array}{l}\text { Genterg atap } \\
\text { masjd } \\
\text { mengeunakan } \\
\text { genteng keramik } \\
\text { dicat dergan } \\
\text { warna hijar. }\end{array}$ & $\begin{array}{l}\text { Genting pada } \\
\text { bargunanmasid ini } \\
\text { merggunakan } \\
\text { genterg berwarna } \\
\text { hijaukarena } \\
\text { melambangkan sirat } \\
\text { hammoni antera } \\
\text { agama islam dan } \\
\text { tionghge. }\end{array}$ \\
\hline $\begin{array}{c}\text { Wenshou' } \\
\text { Omamen Atag }\end{array}$ & & & $\begin{array}{l}\text { Terdapat omamen } \\
\text { atap saperti } \\
\text { bargunan } \\
\text { tradisianal d } \\
\text { wilaybh selistan } \\
\text { ona. }\end{array}$ & 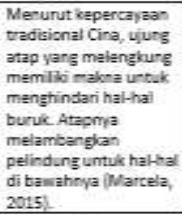 \\
\hline $\begin{array}{l}\text { Wodong// } \\
\text { Penutup } \\
\text { Genterg }\end{array}$ & & & $\begin{array}{l}\text { Tidak terdapat } \\
\text { ormamen } \\
\text { penutug } \\
\text { genteng pada } \\
\text { atap masjid. }\end{array}$ & 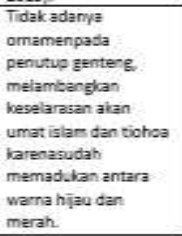 \\
\hline Bertuk.Atap & & & $\begin{array}{l}\text { Atap masid } \\
\text { berbentuk } \\
\text { peiana dengan } \\
\text { ujurg bubungan } \\
\text { berbentuk } \\
\text { pointed tip } \\
\text { namun di } \\
\text { tambahikan } \\
\text { kubah seperti } \\
\text { masjid pada } \\
\text { urumnya. }\end{array}$ & $\begin{array}{l}\text { Merupakan bentuk } \\
\text { akulturasi antara } \\
\text { budaya Cina dan } \\
\text { Islam, }\end{array}$ \\
\hline
\end{tabular}


KESIMPULAN DAN SARAN

Elemen Arsitektur Cina Pada Masjid Babah Alun

Dari hasil penelitian ini, disimpulkan bahwa Masjid Babah Alun yang diambil sebagai

objek penelitian memiliki beberapa penerapan elemen arsitektur Cina. Berikut kesimpulannya :

Lantai: Lantai memiliki podium dan material lantai terbuat dari lantai keramik.

Dinding: Dinding terbuat dari material bata dan semen namun berwarna cream tanpa motifberbeda dengan bangunan tradisional cina.

Duogong/Ornamen Penahan Balok: Tidak terdapat ornamen struktur penahan balok pada bangunan masjid.

Genteng: Genteng atap masjid menggunakan genteng keramik dicat dengan warna hijau.

Wenshou/Ornamen Atap: Terdapat ornamen atap seperti bangunan tradisional di wilayah selatan cina yaitu qiaojiao.

Wadang/Penutup Genteng: Tidak terdapat ornamen penutup genteng pada atap masjid.

Bentuk Atap: Atap masjid berbentuk pelana dengan ujung bubungan berbentuk pointed tip namun ditambahkan kubah seperti masjid pada umumnya.

Dari kesimpulan di atas elemen arsitektur Cina yang diterapkan pada Masjid Babah Alun adalah sebagai berikut :

- Lantai Masjid

- Genteng Masjid

- Wenshou/Penutup Genteng

- Bentuk Atap

Nilai Filosofis Penggunaan Elemen Arsitektur Cina Pada Masjid Babah Alun

Dari hasil penelitian ini, disimpulkan bahwa Masjid Babah Alun yang diambil sebagai objek penelitian memiliki nilai filosofis dari penggunaan elemen arsitektur Cina. Berikut kesimpulannya :

Baoding/Ornamen Ujung Atap : Kaligrafi ini ditempatkan di ujung tertinggi untuk menunjukkan bahwa Tuhan memiliki tingkat tertinggi dari semuanya.

Wenshou/Ornamen Atap: Menurut kepercayaan tradisional Cina, ujung atap yang melengkung memiliki makna untuk menghindari hal-hal buruk. Atapnya melambangkan pelindung untuk hal-hal di bawahnya (Marcela, 2015).

Bentuk Atap: merupakan bentuk akulturasi antara budaya Cina dan Islam.

Penggunaan warna merah: terdapat pada kolom, dinding, dan ornamen-ornamen bangunan. Warna merah merupakan warna api dan warna api dan warna arah selatan. Warna merah merupakan lambang keberuntungan dan kemakmuran, sekaligus melambangkan kebenaran dan ketulusan hati.

Penggunaan warna kuning: Warna kuning merupakan warna tanah. Dalam arsitektur Tionghoa, dinding dan ornamen hias pada bangunan kelenteng seringkali diberi warna kuning. Warna kuning merupakan lambang kemakmuran dan sikap optimis, sekaligus lambing umur panjang dan kekayaan. Dalam sejarah Tionghoa, pakaian berwarna kuning hanya boleh dikenakan oleh Kaisar.

Penggunaan warna hijau: Dalam arsitektur Tionghoa, warna hijau diterapkan sebagai elemen dekorasi, balok, dan braket. Warna hijau merupakan simbol kayu dan melambangkan keberuntungan (rezeki yang melimpah).

\section{KESIMPULAN AKHIR}

Dari karakteristik arsitektur Masjid Babah Alun yang dijadikan obyek penelitian dapat diketahui bahwa 4 dari 7 elemen arsitektur serta ditambah 6 point nilai filosofis dari penggunaan elemen arsitektur Cina yang menyimpulkan bahwa Masjid Babah Alun termasuk bangunan yang mengaplikasikan arsitektur Cina. 


\section{DAFTAR PUSTAKA}

Acculturation and Adaptation. Handbook of cross-cultural psychology: Social behavior and applications volume3. Boston: Allyn \& Bacon

Berry, J.W., Sam, D.L. 1999. Batavia VOC (Terj). Jakarta: Pustazet Perkasa

Charis Chan. 1991. Imperial China. London: Penguin Books

Du Feibao. 2008. Things Chinese. China: China Travel \& TourismPress

Fanani, Achmad. 2009. Arsitektur Masjid. Yogyakarta:Bentang.

Groeneveldt, W.P. 2009. Nusantara dalam CatatanTionghoa. Jakarta: Komunitas Bambu

Hariyono, P. 1993. Kultur Cina dan Jawa, Pemahaman Menuju Asimilasi Kultural. Jakarta: Pustaka Sinar Harapan

Handinoto. 2009. Perkembangan Arsitektur Tionghoa di Indonesia. Dalam AH Kustara(Ed.). Peranakan Tionghoa Indonesia: Sebuah Perjalanan Budaya (hlm.70-92). Jakarta: PT Intisari Mediatama dan Komunitas-Lintas Budaya Indonesia. https://ramadhan. republika.co.id/berita/qc9z6e430/jusuf-hamkamualaf-yang-ingin-bangun-seribu masjid

Kinasih, Ayu Windy. 2007. Identitas Etnis Tionghoa Di Kota Solo. Yogyakarta: FISIPOL UGM.

Pratiwo. 2001. Arsitektur Tradisional Tionghoa dan Pengembangan Kota. Yogyakarta: Penerbit Ombak

Ronald G. Knapp. 2000. China's Old Dwellings, Honolulu: University ofHawai'i Press. (hal.72)

Yudoseputro, Wiyoso. 1998. Chinese Influences in Indonesian Art, dalam Hilda Soemantri, et al., ed. Indonesian Heritage: Visual Art. Singapore: Archipelago Press. 